\title{
Promoter trap strategy for gene expression analysis under stress conditions of $M$. tuberculosis latency
}

\author{
Anant Yadav, Shivani Sood, Rahul Shrivastava* \\ From 2nd International Science Symposium on HIV and Infectious Diseases (HIV SCIENCE 2014) \\ Chennai, India. 30 January - 1 February 2014
}

\section{Background}

Tuberculosis, caused by Mycobacterium tuberculosis, still remains a significant bacterial killer globally accounting for $\sim 2$ million deaths annually. The uniqueness of the infection lies in the competence of the etiological agent to remain dormant in the human body for extended periods of time, escaping the body's defense mechanisms. The ineffectiveness of the currently used antimycobacterials against latent mycobacteria warrants for discovery of novel drugs and drug targets. New methods are also required for the identification, analysis and validation of drug targets against latent mycobacteria.

\section{Methods}

A promoter trap vector with lacZ reporter system was constructed. For validation of the vector, upstream sequences of genes known to be involved in $M$. tuberculosis latency along with suitable positive and negative controls were PCR amplified and cloned into the shuttle vector containing promoterless lac $Z$ reporter system, to yield recombinant constructs. The recombinant constructs were then electroporated into $M$. smegmatis to obtain recombinant mycobacterial strains. All such strains were individually subjected to stress conditions associated with M. tuberculosis latency.

\section{Results}

Validation of the promoter trap vector was done by expression analysis of lac $Z$ reporter using a $\beta$-galactosidase assay. Genes known to be involved in the latency of $M$. tuberculosis showed appreciable levels of $\beta$-galactosidase

* Correspondence: rahulmicro@gmail.com

Department of Biotechnology and Bioinformatics, Jaypee University of Information Technology, Waknaghat, Solan-173234, Himachal Pradesh, India expression under anaerobiosis as well nutrient starvation conditions in comparison to the negative control strain.

\section{Conclusion}

This promoter trap strategy can be exploited for expression analysis and validation of drug targets deduced from various non conclusive strategies such as bioinformatic analysis and microarray. This can also be utilized for determination of new drug targets by construction of genomic library.

Published: 27 May 2014

doi:10.1186/1471-2334-14-S3-O13

Cite this article as: Yadav et al:: Promoter trap strategy for gene expression analysis under stress conditions of $M$. tuberculosis latency. BMC Infectious Diseases 2014 14(Suppl 3):013.

Submit your next manuscript to BioMed Central and take full advantage of:

- Convenient online submission

- Thorough peer review

- No space constraints or color figure charges

- Immediate publication on acceptance

- Inclusion in PubMed, CAS, Scopus and Google Scholar

- Research which is freely available for redistribution 